\section{Internal audit practices and trends in} Romania and
worldwide

Ionela-Corina CHERSAN, Alexandru loan Cuza University of laşi, E-mail: macov@uaic.ro

\section{Alsstract}

For a long time, internal audit has been seen mainly as an activity of providing assistance to external auditors, especially by checking up accounting procedures as part of the internal control evaluation process. At present, while this role of the internal auditor has not disappeared, the role of consultant manager has gained primary importance. In this context, it is increasingly obvious that the professional profile of the internal auditor will undergo changes generated not only by the changes in the role that he or she fulfils, but also by the challenges that the business world needs to deal with: risk management, increasingly sophisticated information technology, data mining etc. This study relies on the information provided by The Institute of Internal Auditors Research Foundation - IIARF which includes data extracted from The Global Internal Audit Common Body of Knowledge - CBOK database, and it aims to point out the practices and trends regarding internal audit in Romania and worldwide, and, respectively, the competencies traditionally required from internal auditors, their views on the skills they master and on the scope of their further skill development.

Keywords: CBOK, IIA, internal audit, skills, trends. JEL Classification: M42, M48.

To cite this article:

Chersan, I.C. (2016), Internal audit practices and trends in Romania and worldwide, Audit Financiar, vol. XIV, no. 9(141)/2016, pp. 987-1002, DOI: 10.20869/AUDITF/2016/141/987

To link to this article:

http://dx.doi.org/10.20869/AUDITF/2016/141/987 


\section{Introduction}

Over the past years there have emerged multiple opportunities for internal auditors, but these opportunities can only be taken by auditors with more and more complex knowledge and skills. Some authors noticed the new responsibilities that internal auditors must manage and the new skills that they need. Thus, Ratliff and Reding (2002) claimed that "the auditors of the twenty-first century need to be prepared to 'audit' everything operations (including those particular to internal control), performance, information and information systems, compliance with the law, financial statements, fraud, environmental reports and performance and quality reports". Therefore, auditors need:

- Analytical skills and critical thinking;

- An efficient method to adequately understand any entity or activity to be audited: person, organization or system;

- The new concepts, principles and techniques specific to internal control;

- Awareness and understanding of risks and opportunities characteristic to auditors, as well as to those to be audited;

- The ability to generate general and specific audit objectives for any audit assignment;

- The ability to select, collect (using a large array of auditing procedures), evaluate and document auditing evidence, using statistic and non-statistic procedures;

- The ability to report progress on the audit assignments, in varied forms and to various beneficiaries;

- The ability to assess how recommendations are complied with;

- High professional ethics;

- The ability to use modern auditing techniques.

Similarly, Moeller and Witt (1999) believe that a successful internal auditor masters the following personal skills, which complement technical and professional skills: fairness and integrity, loyalty to the organization's interests, modesty, professional calm, empathy, coherence, curiosity, critical attitude, vigilance, tenacity, energy, self-trust, courage and the ability to make value judgments.
Considering these skills as significant for a high-quality activity of internal auditors, in this article we aim to present comparative analyses regarding:

a. The Romanian auditors' level of training and skills;

b. The way in which they carry out their activity (relationship with organization management structures, reporting);

c. Trends regarding various audit techniques and tools.

\section{Literature review}

Over time, numerous studies on the evolution of internal audit have been carried out internationally (Moeller and Witt, 1999; Anderson, 2003; Ramamoorti, 2003; Ratliff and Reding, 2002; Flemming Ruud, 2003; Moeller, 2005), and lately they have been carried out in Romania as well (Boța-Avram and Popa, 2011; Precob and RusuBuruiană, 2015).

Moeller and Witt (1999) and Moeller (2005) carried out the most encompassing studies on internal audit. The authors deal with internal audit in an exhaustive and detailed manner. They begin with the definition and evolution of internal audit and end with a discussion on the current trends in the field, takling subjects such as the way in which internal audit relates to the management structures of organizations, the way in which internal audit is managed as a profession (valid regulations), the impact of information systems on internal audit, techniques and instruments used in assurance and advisory assignments.

After presenting, from a historical perspective, the evolution of internal audit and its objectives, Ramamoorti (2003) describes contemporary internal audit practices. He mentions the influence that changes in the business environment have on internal audit, namely, the need to assume new roles and responsibilities.

Technological development and its impact on businesses were the object of Flemming Ruud's (2003) research. He too pointed out the evolution of internal audit, seeing that it evolved from providing assurance services to consulting, he discussed the new role internal auditors need to assume and the relationships they need to maintain and develop with company management structures.

In the context of recent financial scandals, Anderson (2003) formulated several questions on the plus value 
that internal audit brings its "clients", a category in which he includes: those who are the object of the internal audit asignments, managers, company management structures, external auditors, regulating bodies, customers and suppliers. He also describes the tensions existing between these beneficiaries, due to different and sometimes contradictory requirements that they make to internal auditors, and wonders how balance could be reached in the management of their relationships.

Ratliff and Reding (2002) mention the significant expansion of the area in which internal auditors activate. This impacts the level of knowledge and the abilities that internal auditors need to have and improve in order to meet companies' increased demands.

Boța-Avram and Popa (2011) highlighted the atypical evolution of internal audit in Romania, namely its initial development in the public sector and only later in the private sector. This is at least partially explained by the cultural peculiarities of the Romanian economic environment.

An empirical and more recent study, carried out by Precob and Rusu-Buruiană (2015), describes the current characteristics of the internal auditing carried out by Romanian auditors, the internal auditors' opinions on their role in Romanian firms and the auditors' opinions on the subsequent evolution of internal audit.

\section{The purpose of the research and the methodology used}

The paper relies on the specialized audit literature and on the database provided by the Institute of Internal Auditors Research Foundation - IIARF, which contains data taken from the Global Internal Audit Common Body of Knowledge - CBOK. Also, for the comparative analyses mentioned in the Introduction section and for the formulation of conclusions, we used the information obtained, after working with the same database, by: Bailey (2010), lyer (2016), Rose (2015) and Rose (2016), Seago (2015), Rittenberg (2016), Tsintzas (2016), BarrPulliam (2016), Harrington and Piper (2015). All these studies have been carried out using data provided by $\mathrm{CBOK}$, while the analyses from these studies were concerned with the internal auditors' activities and features at a global level.

Our study aims to compare results obtained globally, in Europe and Romania, after the CBOK study carried out in 2010, on the level of education and the skills of internal auditors, the entities that they work for, the trends in using various techniques and tools for auditing assignments, the certifications and the experience that they have.

To process the data, we used the above mentioned database, and used the $Q$ Reader computer application to visualize the data and to select relevant data for our study. Then we used the Microsoft Office-Excel facilities. For this purpose, we extracted information from the CBOK database on the global, European and Romanian results, concerning:

- the internal auditors' education;

- the university degree that they hold; and

- the type of organization that they currently work for.

These elements were the foundation for the description of the representative group. We then proceeded to the proper data comparison and explanation of results.

\section{Description of the sample}

Although various studies have been conducted throughout the years, the most exhaustive one, whose results have been synthesized in a report, is the 2010 CBOK study. It was carried out based on answers received from 13,582 persons from 107 countries (22 languages), with varied answer rates per question. Meanwhile, in 2015, a more elaborate study was carried out, but its final results have not yet been published in full. Therefore, we will use the data provided by the 2015 study in a future research. After presenting the information which has been processed based on CBOK data, we will present the content of the question as it appeared in CBOK.

From Romania, in the 2010 study, 104 internal auditors answered the CBOK questionnaire, with the following distribution regarding their education, compared to the global and European situation. 


\section{Table 1. Comparative analysis regarding the education of internal auditors who answered the 2010 CBOK questionnaire $^{1}$}

\begin{tabular}{|l|r|r|r|}
\hline $\begin{array}{l}\text { The highest level of formal education (not certification) } \\
\text { completed }\end{array}$ & Global & \multicolumn{1}{c|}{ Europe } & \multicolumn{1}{c|}{ Romania } \\
\hline Secondary/high school education & $4.36 \%$ & $10.44 \%$ & \\
\hline $\begin{array}{l}\text { Undergraduate diploma/technical certificate or associate } \\
\text { degree }\end{array}$ & $3.82 \%$ & $4.94 \%$ & - \\
\hline Bachelors/diploma in business & $29.40 \%$ & $16.17 \%$ & $38.46 \%$ \\
\hline Bachelors/diploma in fields other than business & $10.71 \%$ & $7.46 \%$ & $5.77 \%$ \\
\hline Maters in economics & $37.55 \%$ & $41.08 \%$ & $39.42 \%$ \\
\hline Masters/graduate diploma in fields other than business & $12.12 \%$ & $16.45 \%$ & $11.54 \%$ \\
\hline Doctoral degree (PhD or higher) & $2.04 \%$ & $3.46 \%$ & $4.81 \%$ \\
\hline \multicolumn{1}{c}{ Total } & $100 \%$ & $100 \%$ & $100 \%$ \\
\hline
\end{tabular}

1 Based on answers to question Q7. What is your highest level of formal education (not certification) completed?

Source: Author's processing based on the CBOK 2010 database

One can notice that only in Romania the internal auditors hold at least one university degree, since otherwise it is impossible for them to work as internal auditors. Consequently, one can see that in Romania the number of internal auditors with a BA in Economics (38.46\%) is higher than globally $(29.40 \%)$ and in Europe (16.17\%). Also, possibly due to prejudice which deems internal audit activities to be focused on financial accounting aspects, in Romania there is the lowest number of internal auditors $(5.77 \%)$ who hold a university degree in a field other than Economics, as compared to the global $(10.71 \%)$ and the European $(7.46 \%)$ average.

\section{Table 2. Comparative analysis of the academic majors of the internal auditors who answered the 2010 CBOK questionnaire ${ }^{2}$}

\begin{tabular}{|c|c|c|c|}
\hline $\begin{array}{l}\text { The academic major(s) or the most significant } \\
\text { fields of study }\end{array}$ & Global & Europe & Romania \\
\hline Accounting & $50.36 \%$ & $30.66 \%$ & $35.58 \%$ \\
\hline General business/management & $25.19 \%$ & $32.19 \%$ & $37.50 \%$ \\
\hline Finance & $24.93 \%$ & $28.22 \%$ & $38.46 \%$ \\
\hline Internal auditing & $23.62 \%$ & $27.79 \%$ & $34.62 \%$ \\
\hline Economics & $16.54 \%$ & $29.58 \%$ & $24.04 \%$ \\
\hline External auditing & $12.96 \%$ & $15.62 \%$ & $11.54 \%$ \\
\hline Computer science or information systems & $9.03 \%$ & $9.63 \%$ & $7.69 \%$ \\
\hline Law & $7.02 \%$ & $10.71 \%$ & $8.65 \%$ \\
\hline Other & $5.87 \%$ & $6.11 \%$ & $3.85 \%$ \\
\hline Engineering & $4.23 \%$ & $5.84 \%$ & $13.46 \%$ \\
\hline Mathematics/statistics & $4.27 \%$ & $6.41 \%$ & $3.85 \%$ \\
\hline $\begin{array}{l}\text { Arts or humanities (e.g. languages, literature, history, } \\
\text { psychology) }\end{array}$ & $4.21 \%$ & $4.95 \%$ & $0.00 \%$ \\
\hline $\begin{array}{l}\text { Other science or technical field (e.g. physics, } \\
\text { chemistry, geology, biology) }\end{array}$ & $2.47 \%$ & $3.19 \%$ & $0.00 \%$ \\
\hline
\end{tabular}

2Based on answers to question Q8: What were your academic major(s) or your most significant fields of study? (Choose all that apply) Source: Author's processing based on the CBOK 2010 database 
Regarding the fields in which the internal auditors majored, we note that globally most respondents majored in Accounting (50.36\%). In Romania, the percentage of Accounting majors is $35.58 \%$, and in Europe it is $30.66 \%$. In Romania, the statistics regarding university majors are quite surprising, namely a high percentage of internal auditors $(34.62 \%)$ declare to have majored in an Internal Audit related field, as compared to significantly lower percentages globally (23.62\%) and in
Europe (27.79\%). Also, we can notice the high number of Finance majors (38.46\%) working as internal auditors, compared to the global level $(24.93 \%)$ and the European level (28.22\%). Significant differences are recorded in the case of majors in technical fields, as $13.46 \%$ of Romanian internal auditors participating in the study hold a degree in a technical field, as compared to only $5.84 \%$ in Europe and $4.23 \%$ globally.

\begin{tabular}{l} 
Table 3. Comparative analysis on the type of organization internal auditors answering the 2010 CBOK \\
questionnaire currently work for ${ }^{3}$ \\
\multicolumn{1}{|c|}{ The type of organization }
\end{tabular}

${ }^{3}$ Based on answers to question Q24: What is the type of organization for which you currently work?

Source: Author's processing based on the CBOK 2010 database

The information in Table 3 explains a number of the results in our study because, unlike the global or European situation, where the majority of auditors work for companies listed on the stock exchange or for nonlisted private companies, in Romania, the majority of auditors work in the public sector, where the regulations concerned with organizing and carrying out the activity are different from those of the private sector, being more rigid and having distinct characteristics.

\section{Research results}

In 2013, The Institute of Internal Auditors published the Conceptual Framework regarding the competencies of internal auditors. According to this framework, internal auditors need to be thoroughly skilled in the following ten core areas (IIA, 2013):

1. Professional ethics

2. Internal audit management

3. Application of the International Professional Practices Framework (IPPF)

4. Governance, risk and control

5. Business acumen

\section{Communication}

7. Persuasion and collaboration

8. Critical thinking

9. Internal audit delivery

10. Improvement and innovation.

The first two areas, namely professional ethics and management skills, are fundamental in organizing and delivering any internal audit activity. Professional ethics underlie the general expectations regarding the general behaviour of internal auditors, as a profession, and the competencies in the management of resourses and internal audit activities are essential irrespective of the size of the audit structure.

Professional practices, governance, risk, control and business acumen are considered the auditors' technical skills and are essential to properly deliver any internal audit engagement.

Personal skills (communication, persuasion and collaboration, critical thinking) are important in providing a reasonable certainty that the information, observations and recommendations have the expected impact on the organization. 
The carrying out of any audit assignment requires objectivity, strategic and operational planning skills, as well as a good management of resources.

Finally, improvement and innovation prepare the organization for the necessary changes ensuring a smooth transition to its sustainable growth.

The attributes in the above mentioned conceptual framework were formulated based on the fundamental Principles for professional internal auditing, published in 2015 by the Institute for Internal Auditors (IIA), which states that the activity of the internal auditors must be characterized by the following:

- Integrity;

- Professional competence and scrupulosity;

- Objectivity and self-reliance;

- Is in line with the stategies, objectives and risks of the organiation;

- Appropriate position within the organization and possession of adequate resources;

- Delivers high quality, and is under continuous improvement;

- Efficient communication;

- Provision of assurance based on risk;

- Possession of detailed knowledge of the organization, pro-active and future oriented attitude;

- Promotion of improved activity in the organization.

The analysis of the answers of participants in the 2010 Global Internal Audit Common Body of KnowledgeCBOK showed that internal auditors at all levels thought that the most important three competence areas were:

- Communication skills;

- Competence in problem identification and problem solving;

- Knowledge of legislative changes, changes in professional standards and changes in the business environment.

For a complete analysis of the competencies required from internal auditors, the questionnaire also included items regarding the knowledge that internal auditors consider to be essential for the work that they are engaged in. Thus, in the order of their importance, the areas in which internal auditors believe they must possess adequate knowledge which would enable them to carry out their activity properly, are:
1. Audit;

2. Internal audit standards;

3. Ethics;

4. Fraud awareness;

5. Enterprise risk management;

6. Changes to professional standards;

7. Technical knowledge in the field in which the organization operates;

8. Governance;

9. Financial accounting;

10. Business management;

11. Organizational systems;

12. Strategies and business policies;

13. Organizational culture;

14. Business law and government regulation;

15. Finance;

16. IT/CT;

17. Management accounting;

18. Undestanding of quality frameworks;

19. Economics;

20. Marketing.

Also, the study highlighted the basic skills required from internal auditors at various levels. These were grouped in common skills and specific skills.

The common skills are the most important skills required from internal auditors, irrespective of the level that they are at: internal audit staff, internal audit management and chief audit executive. Each must continually improve these skills, throughout their career.

The specific skills are the five most important skills required from internal auditors at each level. These skills must be developed as auditors occupy higher positions.

Both common and specific skills have been grouped as general, behavioral and technical, and the analysis was carried out depending on the different position that internal auditors can occupy in the internal audit structure of an organization.

General competencies are the skills considered to be essential for the completion of certain tasks. In Table 4 these are presented in the order of their importance, together and individually, for all three internal auditing professional categories. 


\section{Table 4. General competencies required from internal auditors, at global level, based on the position of the auditor ${ }^{4}$}

\begin{tabular}{|c|c|c|c|}
\hline \multirow{2}{*}{$\begin{array}{c}\text { General competencies, ranked by their importance to } \\
\text { internal auditors, regardless of the position ocuppied } \\
\text { by auditors }\end{array}$} & \multicolumn{3}{|c|}{ Order of importance for: } \\
\hline & Internal audit staff & Management & Head of audit function \\
\hline Communication skills & 1 & 2 & 3 \\
\hline Problem identification and solution skills & 2 & 5 & 5 \\
\hline Ability to promote the value of the internal audit activity & 7 & 8 & 1 \\
\hline $\begin{array}{l}\text { Keeping up-to-date with industry and regulatory changes } \\
\text { and professional standards }\end{array}$ & 4 & 4 & 3 \\
\hline Organizational skills & 6 & 1 & 6 \\
\hline Conflict resolution/negotiation skills & 8 & 3 & 4 \\
\hline Staff training and development & 10 & 6 & 7 \\
\hline $\begin{array}{l}\text { Competency with accounting frameworks, tools, and } \\
\text { techniques }\end{array}$ & 3 & 9 & 9 \\
\hline Change management skills & 11 & 7 & 8 \\
\hline Competency with IT/ICT frameworks, tools, and techniques & 5 & 10 & 11 \\
\hline Cultural fluency and foreign language skills & 9 & 11 & 10 \\
\hline
\end{tabular}

${ }^{4}$ Based on answers to question Q76. Please indicate the importance of the following competencies for you to perform your work at your position in the organization.

Source: Author's processing based on the CBOK 2010 database and Bailey, 2010

As for the general specific competencies, the study provided the following results:

- The internal audit staff need especially communicative skills and the ability to use conceptual frames, need problem identification and problem solving skills as well as the ability to use the techniques and tools specific to the fields of accounting and information technology.
- The internal audit managers need management skills, communicative skills, negotiation skills and problem solving skills.

- The chief audit executive needs the ability to enhance the value of the internal audit within the organization, to communicate, negotiate and solve problems, as well as to stay updated on any legislative changes.

\begin{tabular}{|c|c|c|c|}
\hline $\begin{array}{c}\text { General competencies, ranked by their importance } \\
\text { to internal auditors }\end{array}$ & Global & Europe & Romania \\
\hline Communication skills & 1 & 1 & 1 \\
\hline Problem identification and solution skills & 2 & 2 & 5 \\
\hline Ability to promote the value of the internal audit activity & 3 & 4 & 4 \\
\hline $\begin{array}{l}\text { Keeping up-to-date with industry and regulatory changes and } \\
\text { professional standards }\end{array}$ & 4 & 5 & 2 \\
\hline Organizational skills & 5 & 3 & 3 \\
\hline Conflict resolution/negotiation skills & 6 & 6 & 7 \\
\hline Staff training and development abilities & 7 & 8 & 8 \\
\hline $\begin{array}{l}\text { Competency working with accounting frameworks and specific } \\
\text { accounting tools and techniques }\end{array}$ & 8 & 10 & 6 \\
\hline Change management skills & 9 & 7 & 11 \\
\hline Competency working with IT/ICT frameworks, tools, and techniques & 10 & 9 & 9 \\
\hline Cultural fluency and foreign language skills & 11 & 11 & 10 \\
\hline
\end{tabular}

${ }^{5}$ Based on answers to question Q76. Please indicate the importance of the following competencies for you to perform your work at your position in the organization.

Source: Author's processing based on the CBOK 2010 database 
By analyzing Romanian internal auditors' perception of the general competencies that they need in order to perform their specific activities, one can notice that, in Romania, the need to stay up-to-date with legislative changes is felt more accutely, probably as a consequence of the quasi-continuous instability which characterizes the Romanian legislative environment.
Behavioral skills are represented by the way in which one's own actions are perceived by the others, from the perspective of generally accepted standards.

As in the case of general competencies, the following table presents them in the order of their importance, at the level of the three categories of internal audit professionals, taken together and individually.

\section{Table 6. Behavioral skills needed by internal auditors ${ }^{6}$}

\begin{tabular}{|c|c|c|c|c|c|c|c|c|c|}
\hline \multirow{3}{*}{$\begin{array}{l}\text { Behavioral skills, ranked by their importance to } \\
\text { internal auditors, regardless of the position } \\
\text { ocuppied by auditors }\end{array}$} & \multicolumn{9}{|c|}{ Order of importance for: } \\
\hline & \multicolumn{3}{|c|}{ Internal audit staff } & \multicolumn{3}{|c|}{ Management } & \multicolumn{3}{|c|}{$\begin{array}{l}\text { Head of audit } \\
\text { function }\end{array}$} \\
\hline & G & E & $\mathbf{R}$ & G & E & $\mathbf{R}$ & G & $\mathrm{E}$ & $\mathbf{R}$ \\
\hline Confidentiality & 1 & 1 & 1 & 4 & 4 & 10 & 1 & 1 & 1 \\
\hline Objectivity & 2 & 2 & 3 & 11 & 10 & 7 & 6 & 5 & 3 \\
\hline Communication skills & 3 & 3 & 2 & 1 & 1 & 5 & 3 & 3 & 4 \\
\hline Judgment & 4 & 5 & 8 & 7 & 8 & 11 & 8 & 8 & 11 \\
\hline Work well with all levels of management & 7 & 7 & 6 & 10 & 11 & 9 & 7 & 7 & 9 \\
\hline Governance and ethics sensitivity & 8 & 8 & 5 & 5 & 5 & 1 & 4 & 6 & 2 \\
\hline Team player - collaboration/cooperation & 5 & 4 & 4 & 14 & 14 & 13 & 15 & 15 & 10 \\
\hline Relationship building - building bonds & 10 & 10 & 12 & 13 & 13 & 4 & 10 & 10 & 12 \\
\hline Work independently & 6 & 6 & 11 & 15 & 15 & 15 & 14 & 14 & 15 \\
\hline Team building/creating group synergy & 12 & 13 & 13 & 9 & 7 & 12 & 13 & 13 & 14 \\
\hline Leadership & 14 & 14 & 15 & 2 & 2 & 3 & 2 & 2 & 7 \\
\hline Influence - ability to persuade & 9 & 9 & 10 & 6 & 6 & 6 & 5 & 4 & 5 \\
\hline Facilitation & 11 & 11 & 7 & 8 & 9 & 14 & 12 & 11 & 6 \\
\hline Staff management & 15 & 15 & 14 & 3 & 3 & 2 & 9 & 9 & 8 \\
\hline Change catalyst & 13 & 12 & 9 & 12 & 12 & 8 & 11 & 12 & 13 \\
\hline
\end{tabular}

${ }^{6}$ Based on answers to question Q74. Please mark the five most important of the following behavioral skills for each professional staff level to perform their work.

Legend: $G=$ global level; $E$ = European level; $R=$ in Romania

Source: Author's processing based on the CBOK 2010 database and Bailey, 2010

Concerning specific behavioral skills other than confidentiality, which is ranked among the first positions in all categories, the study revealed that:

- Internal audit staff need to be objective, to rely on good professional reasoning and to be able to collaborate, i.e., to be a good team member.

- Internal auditing team/assignment managers need communication skills, leadership skills, governing skills and staff management skills. Also, they need sensitivity to ethical aspects.

- The chief audit executive needs leadership skills, communicative skills, governing skills and persuasive skills, as well as concern for ethical issues.
In Romania, the internal audit managers' views on confidentiality are surprising, since unlike professionals from other countries, they do not see it as an important requirement (ranked 10). Also, there is a contradiction between the option for building relationships (ranked 4) compared to that of organizing teams (ranked 12), and the relative importance given to communication (ranked 5), since both at European level and globally, the communication skills of internal audit engagement leaders are of primary importance.

Technical skills consist in the application of knowledge or skills to an activity. The importance of technical skills 
in carrying out the specific objectives, at the level of the three categories of internal audit professionals, taken together and individually, at global level, at European level, and in Romania, is classified below.

\section{Table 7. Technical skills needed by internal auditors ${ }^{7}$}

\begin{tabular}{|c|c|c|c|c|c|c|c|c|c|}
\hline \multirow{3}{*}{$\begin{array}{l}\text { Tehnical skills, ranked by their importance } \\
\text { to internal auditors, regardless of the } \\
\text { position ocuppied by auditors }\end{array}$} & \multicolumn{9}{|c|}{ Order of importance for: } \\
\hline & \multicolumn{3}{|c|}{ Internal audit staff } & \multicolumn{3}{|c|}{ Management } & \multicolumn{3}{|c|}{ Head of audit function } \\
\hline & G & $E$ & $\mathbf{R}$ & G & E & $\mathbf{R}$ & G & E & $\mathbf{R}$ \\
\hline Understanding business & 3 & 2 & 5 & 1 & 1 & 4 & 1 & 1 & 4 \\
\hline $\begin{array}{l}\text { Risk analysis and control assessment } \\
\text { techniques }\end{array}$ & 1 & 1 & 1 & 4 & 5 & 14 & 3 & 4 & 5 \\
\hline Identifying types of controls & 5 & 5 & 6 & 13 & 13 & 15 & 13 & 13 & 12 \\
\hline $\begin{array}{l}\text { Governance, risk, and control tools and } \\
\text { techniques }\end{array}$ & 12 & 10 & 9 & 8 & 9 & 6 & 4 & 5 & 8 \\
\hline Business process analysis & 4 & 4 & 3 & 7 & 8 & 9 & 10 & 9 & 3 \\
\hline $\begin{array}{l}\text { Data collection and analysis tools and } \\
\text { techniques }\end{array}$ & 2 & 3 & 4 & 17 & 17 & 11 & 17 & 17 & 16 \\
\hline Operational and management research skills & 6 & 7 & 2 & 5 & 4 & 8 & 6 & 3 & 1 \\
\hline Problem solving tools and techniques & 8 & 12 & 18 & 6 & 7 & 7 & 7 & 8 & 10 \\
\hline Negotiating & 14 & 13 & 15 & 3 & 3 & 3 & 2 & 2 & 9 \\
\hline Project management & 13 & 14 & 13 & 2 & 2 & 2 & 5 & 6 & 2 \\
\hline Forensic skills/fraud awareness & 11 & 9 & 7 & 11 & 11 & 18 & 9 & 10 & 6 \\
\hline $\begin{array}{l}\text { Use of IT/ICT and technology-based audit } \\
\text { techniques }\end{array}$ & 7 & 6 & 11 & 15 & 15 & 16 & 15 & 14 & 11 \\
\hline Financial analysis tools and techniques & 10 & 11 & 12 & 14 & 14 & 13 & 14 & 16 & 17 \\
\hline Statistical sampling & 9 & 8 & 8 & 18 & 18 & 17 & 18 & 18 & 18 \\
\hline Forecasting & 16 & 16 & 10 & 9 & 6 & 1 & 8 & 7 & 7 \\
\hline Total quality management & 17 & 17 & 14 & 10 & 10 & 5 & 11 & 11 & 14 \\
\hline ISO/quality knowledge & 15 & 15 & 17 & 16 & 16 & 12 & 16 & 15 & 13 \\
\hline Balanced scorecard & 18 & 18 & 16 & 12 & 12 & 10 & 12 & 12 & 15 \\
\hline
\end{tabular}

${ }^{7}$ Based on answers to question Q75. Please mark the five most important of the following technical skills for each level of professional staff to perform their work.

Legend: $G=$ global level; $E=$ European level; $R=$ in Romania

Source: Author's processing based on the CBOK 2010 database and Bailey, 2010

The specific technical requirements that the three categories of professionals need are presented below.

- The internal audit staff need thorough knowledge of risk analysis techniques, of data collection and analysis instruments and techniques, the capacity to understand and analyse businesses and to identify control categories.

- The internal audit managers need the ability to understand businesses, skills in the field of operational and management research, in project management, as well as good negotiating skills.

- The chief audit executive needs to thoroughly understand businesses, to be a good negotiator and a good project manager, and also to master the tools and techniques specific to governance, risk analysis, and control assessment.

Regarding the technical skills that they should possess, it is significant that Romanian internal auditors do not rate as particulalrly important the understanding of businesses, as it is the case with audit managers and chief audit executives in other countries. The place (14) occupied in the views of Romanian internal audit managers by the need to know the "Techniques of risk analysis and control evaluation" is also surprising, since for auditors in similar positions in other countries, this component ranked fifth, at its lowest. 
Many answers given by Romanian internal auditors regarding the categories of knowledge and competencies that they need can be accounted for by the age of the internal audit position in Romanian organizations. The data analysed show that in Romania, in 2010 , most organizations $(86.42 \%$ ) had had the internal audit position for less than 10 years, and only $1.23 \%$ had had it for over 25 years (Table 8 ). In fact, the latter must be the case of the internal audit function in an international or multinational company activating in Romania as well, since before 1989 such an activity in a Romanian firm could not take place.

\section{Table 8. The age of the internal audit activity in organizations ${ }^{8}$}

\begin{tabular}{|l|r|r|r|}
\hline How long has your organization's internal audit activity been in place? & \multicolumn{1}{|c|}{ Global } & \multicolumn{1}{|c|}{ Europe } & \multicolumn{1}{c|}{ Romania } \\
\hline $0-10$ years & $44.83 \%$ & $48.33 \%$ & $86.42 \%$ \\
\hline $11-25$ years & $30.34 \%$ & $28.16 \%$ & $12.35 \%$ \\
\hline $26-50$ years & $17.44 \%$ & $15.26 \%$ & $1.23 \%$ \\
\hline $51-100$ years or more & $7.38 \%$ & $8.25 \%$ & $0.00 \%$ \\
\hline
\end{tabular}

${ }^{8}$ Based on answers to question Q12. Specify your professional experience (please mark all that apply).

Source: Author's processing based on the CBOK 2010 database

Note Q6. How long has your organization's internal audit activity been in place?

Unlike in Romania, where the position of internal auditor is relatively recent, globally and in Europe the activity is significantly older, since about $25 \%$ of the companies have had the activity organized for over 25 years. In fact, at global level, in over $55 \%$ of the firms, internal audit is past 10 years old, and in Europe, over $50 \%$ of the firms have been running the internal audit activity for more than 10 years.

The relatively short time that internal audit has had in Romania explains why the number of internal auditors who declare that they have skills in fields such as accounting, management, finance, IT, technical or other fields than those listed is higher than at global or European level.

\section{Table 9. The professional experience of internal auditors}

\begin{tabular}{|l|r|r|r|}
\multicolumn{1}{|c|}{ Professional experience } & \multicolumn{1}{c|}{ Global } & \multicolumn{1}{c|}{ Europe } & \multicolumn{1}{c|}{ Romania } \\
\hline Internal auditing & $93.15 \%$ & $93.45 \%$ & $96.15 \%$ \\
\hline External (independent or public) auditing & $34.76 \%$ & $28.64 \%$ & $24.04 \%$ \\
\hline Management & $35.20 \%$ & $31.69 \%$ & $47.12 \%$ \\
\hline Accounting & $38.90 \%$ & $29.57 \%$ & $56.73 \%$ \\
\hline Finance & $25.28 \%$ & $26.11 \%$ & $38.46 \%$ \\
\hline IT/ICT & $10.81 \%$ & $11.96 \%$ & $15.38 \%$ \\
\hline Engineering & $3.99 \%$ & $4.50 \%$ & $13.46 \%$ \\
\hline Other & $15.68 \%$ & $20.78 \%$ & $24.04 \%$ \\
\hline
\end{tabular}

${ }^{1}$ Based on answers to question Q12. Specify your professional experience: (please mark all that apply).

Source: Author's processing based on the CBOK 2010 database

As one can see in the sample presentation section (Table 2), in Romania, the most frequent university degree among internal auditors included in the research is not accounting (first place globally), but finance, followed by management and internal audit. Nevertheless, more than half of the Romanian internal auditors questioned (56.73\%) declare to be experienced in accounting. Anyway, a striking majority $(96.15 \%)$ declare to have experience as internal auditors. An interesting and predictible aspect is that the number of those who declare to be experienced in a technical field $(13.46 \%)$ equals the number of those who declare to have majored in a technical field.

In order to understand the relationship with the management and executive structures within the 
organization, we considered it important to analyse to whom the internal audit report is addressed. Thus, as one can see in Table 10, the results were close for the three analysed groups, yet globally, there is a higher rate of reporting to the audit committees. A possible explanation could be that not all jurisdictions share the legal requirement to have an audit committee. For example, in Romania, the Company Law rules the possibility to organize audit committees, without making it compulsory. Also, a study published in 2005 by The International Organization of Securities Commissions (IOSCO, 2005) showed that there is a specific legislation or another type of regulation concerning the requirement to have audit committees in only $53 \%$ of the jurisdictions where IOSCO members are based. In emerging countries, such requirements are minimal or absent. Only chief audit executives were asked to answer this question.

\section{Table 10. The destination of internal auditors reports ${ }^{10}$}

\begin{tabular}{|c|c|c|c|}
\hline Where do you administratively report (direct line) in your organization & Global & Europe & Romania \\
\hline Audit committee, & $34.35 \%$ & $28.32 \%$ & $22.22 \%$ \\
\hline Chief Executive Officer (CEO)/presidenthead of government agency & $42.72 \%$ & $51.80 \%$ & $55.56 \%$ \\
\hline Chief financial officer (CFO)/vice president of finance or Other & $22.93 \%$ & $19.88 \%$ & $22.22 \%$ \\
\hline
\end{tabular}

${ }^{10}$ Based on answers to question Q14. Where do you administratively report (direct line) in your organization?

Source: Author's processing based on the CBOK 2010 database

The explanation above can be easier understood if we analyse Figure 1: the extent to which firms have organized audit committees. In Romania, the low rate of reporting to an audit committee is justified by its absence in many entities. As seen above, this is the case of many internal auditors working for public institutions.

\section{Figure 1. The existence of audit committees in companies ${ }^{11}$}

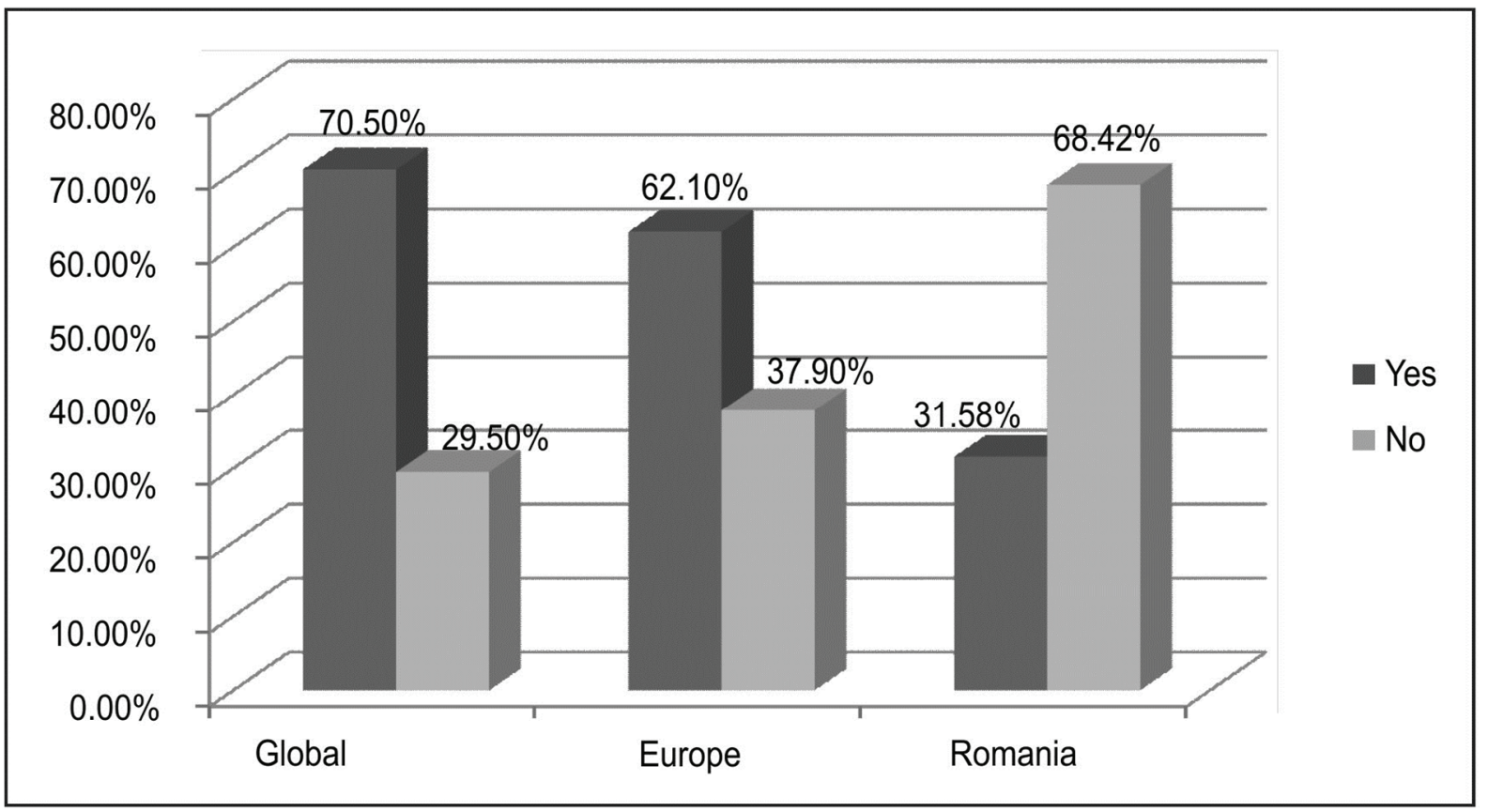

11 Based on answers to question Q26. Is there an audit committee or equivalent in your organization?

Source: Author's processing based on the CBOK 2010 database 
An indicator where Romania rates above the European and global average is the number of 40 hours of formal

\section{Figure 2. 40 hours of formal training per year ${ }^{12}$}

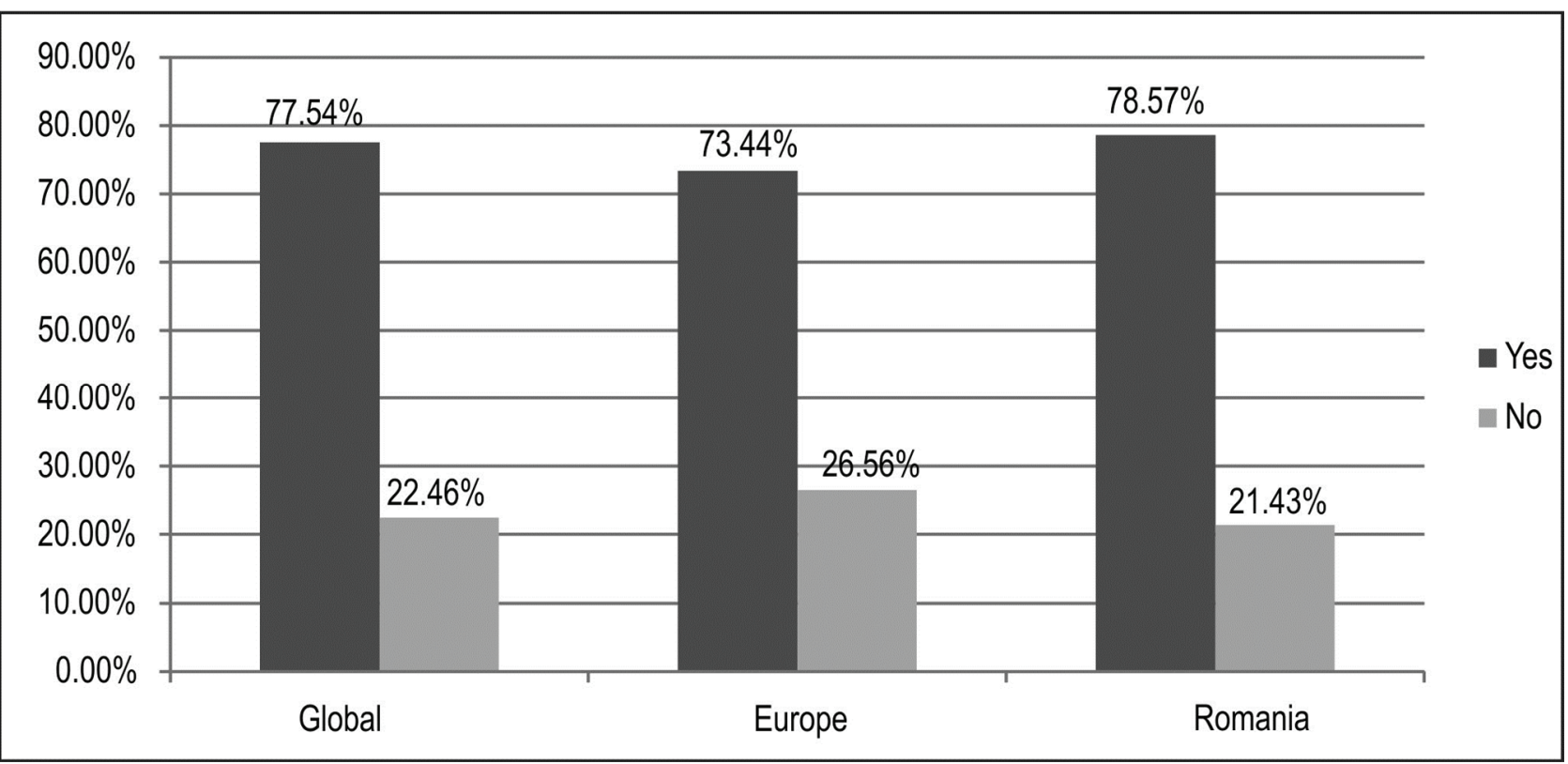

12 Based on answers to question Q15. Do you receive at least 40 hours of formal training per year? Source: Author's processing based on the CBOK 2010 database

If we analyse the distribution of internal auditors based on the category of organizations that they work for

(Figure 3), we note that in Romania almost half of the internal auditors (48\%) are employed in national organizations, which is explained by the fact that they work mainly in the public sector.

\section{Figure 3. The casting of internal auditors based on geographical position of the organzation} for which they work ${ }^{13}$

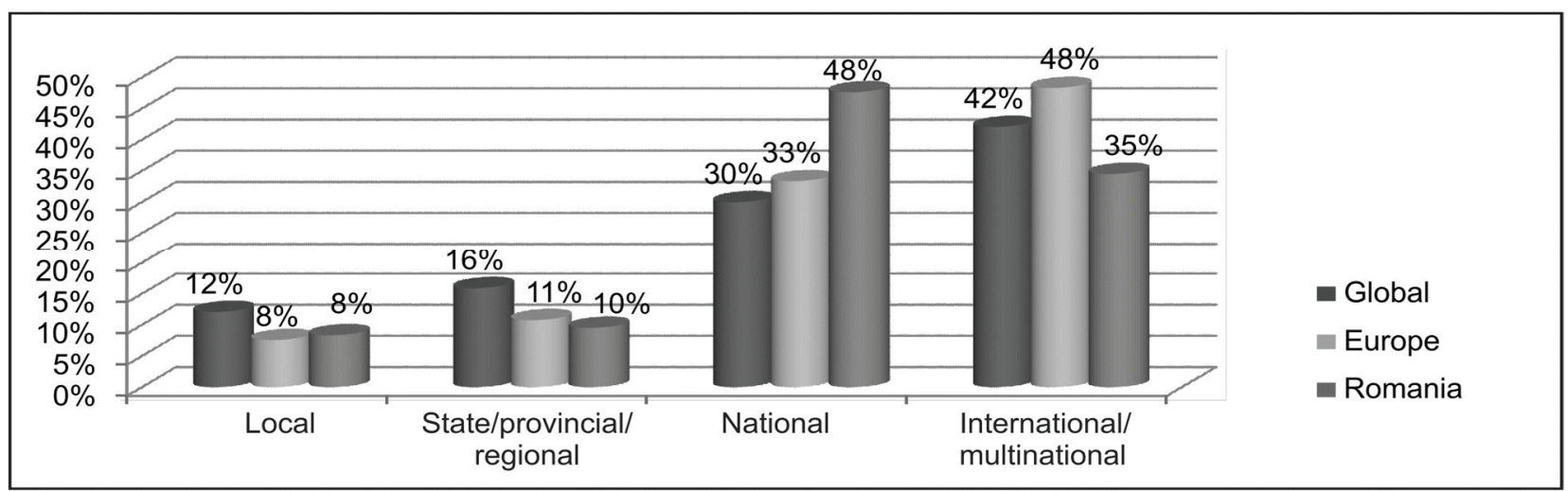

13 Based on answers to question Q21. Is your organization [local, state, national, international ...]?

Source: Author's processing based on the CBOK 2010 database 
We can notice that at global level and especially in Europe, there is a higher number of internal auditors employed in international or multinational companies. In Romania as well, the number of internal auditors employed in international or multinational companies is significant (35\%).

After discussing the characteristic features of internal audit in Romania and worldwide and after identifying the competencies and knowledge that auditors need to carry out their assignments, we propose to identify the trends in the future use of techniques and tools which are currently used by internal auditors. Thus, as one can see in Table 11, in order to deliver high quality internal audit, internal auditors believe that the most useful are: riskbased planning, various ways of electronic communication, analytical review, statistic sampling, data mining techniques and computer-assisted audit techniques. Except for data mining techniques, ranked 12 by Romanian auditors, the rest of the techniques and tools are valued equally by internal auditors worldwide.

\section{Table 11. Internal auditors' preference for the use of various audit techniques and tools ${ }^{14}$}

\begin{tabular}{|l|r|r|r|}
$\begin{array}{c}\text { The extent the internal audit activity uses or plans } \\
\text { to use the following audit tools or techniques } \\
\text { on a typical audit engagement }\end{array}$ & Global & Europe & Romania \\
\hline Risk-based audit planning & 1 & 1 & 1 \\
\hline Control self-assessment & 8 & 8 & 6 \\
\hline Balanced scorecard & 14 & 14 & 13 \\
\hline Benchmarking & 10 & 9 & 7 \\
\hline Analytical review & 3 & 3 & 5 \\
\hline Data mining & 6 & 6 & 12 \\
\hline Statistical sampling & 4 & 5 & 2 \\
\hline Computer assisted audit technique & 7 & 7 & 9 \\
\hline Total quality management techniques & 15 & 15 & 15 \\
\hline Continuous/real-time auditing & 11 & 12 & 8 \\
\hline Electronic work papers & 5 & 4 & 4 \\
\hline Flowchart software & 9 & 10 & 11 \\
\hline Process mapping application & 12 & 11 & 16 \\
\hline Process modelling software & 16 & 16 & 14 \\
\hline Other electronic communication (e.g., Internet, E-mail) & 2 & 2 & 3 \\
\hline The llA's quality assessment review tools & 13 & 13 & 10 \\
\hline
\end{tabular}

${ }_{14}$ Based on answers to question Q69. Indicate the extent the internal audit activity uses or plans to use the following audit tools or techniques on a typical audit engagement.

Source: Author's processing based on the CBOK 2010 database

With respect to the professional certifications of Romanian internal auditors, we note a low percentage in the number of Certified Internal Auditors (CIA). Other certifications are also absent, except for a small number of internal auditors.

The situation relative to the most important professional certifications that internal auditors have or plan to obtain in the following five years is presented below. The auditors were asked to name all their qualifications.
We note that Romanian internal auditors score better at planning to obtain certifications rather than at having them. Globally and at European levels the situation looks much better, meaning that most internal auditors have already obtained Certified Internal Auditor Certificates (CIA), Chartered Professional Accountant or Financial Auditor (CPA) Certificates and Certified Information Systems Auditor (CISA) Certificates. Also, as in Romania, those who work in internal audit structures were interested in obtaining a Certified Internal Auditor Certificate. 
Table 12. The professional certifications Romanian internal auditors have or plan to obtain ${ }^{15}$

\begin{tabular}{|l|c|c|}
\multicolumn{1}{|c|}{ Professional certifications } & Currently & $\begin{array}{c}\text { Planned additions over the } \\
\text { next five years }\end{array}$ \\
\hline CIA - Certified Internal Auditor & $17.31 \%$ & $51.92 \%$ \\
\hline CPA - Certified Public Accountant & $1.92 \%$ & $8.65 \%$ \\
\hline CGAP - Certified Government Audit Professional & $10.58 \%$ & $12.50 \%$ \\
\hline CFSA - Certified Financial Services Auditor & $3.85 \%$ & $18.27 \%$ \\
\hline CISA - Certified Information Systems Auditor & $1.92 \%$ & $5.77 \%$ \\
\hline Other & $25.00 \%$ & $2.88 \%$ \\
\hline None & $16.35 \%$ & $1.92 \%$ \\
\hline
\end{tabular}

${ }^{15}$ Based on answers to question Q11. Which professional certifications and/or qualifications do you have related to internal auditing? (Choose all that apply).

Source: Author's processing based on the CBOK 2010 database

\section{Bonclusion and discussions}

Our research has revealed that the demand for more competencies and knowledge among internal auditors results from the evolution of the internal auditor's position towards new roles. In this context we mention the results of a study conducted by Ernst \& Young in 2013, titled "Key Findings from the Global Internal Audit Survey 2013", which identified and synthetized several aspects concerning internal audit, as follows:

- Internal auditing is increasingly expected to offer stakeholders a more and more accurate perspective on business, as well as to play the role of a strategic advisor for an organization.

- Expectations that internal audit be more and more involved in identifying, assessing and monitoring resources have increased.

- It is a fact that internal auditors lack data analysis skills, business strategy skills, risk management skills, fraud prevention and detection skills, and most times they are not experienced in the field in which the orgnization that they serve operates.

As compared to our results based on the data provided by CBOK (2010), the most recently published studies, based on the 2015 CBOK data provide a more encompassing image of the current realities and trends in the internal auditors' activity. Thus, Rose (2015) conducted a complex analysis of the way in which internal auditors self-assess their competencies. Rittenberg (2016) conducted a comparison between the 2010 and 2015 results concerning the interaction between internal auditors and audit committees. Piper and Harrington (2015) provide several ideas concerning the manner in which internal auditors can build a successful career in the increasingly changing business world.

The role of studies carried out by the organizations involved in regulating, promoting and assessing the internal audit activity globally is to provide a guide for professionals to develop the competencies that they need in order to perform a high quality internal auditing activity, and to plan their personal development. It is a generally accepted fact that, for internal auditors, professional experience is essential in their activity. However, even though experience can only be gained in time, anyone can invest in their personal development, including by obtaining internal audit certifications.

\section{Acknowledgments}

For the completion of this research, the data was obtained from the databases CBOK 2010 and CBOK 2015 Global Internal Audit Practitioner Survey (Altamonte Springs, Florida, USA: The Institute of Internal Auditors Research Foundation). 


\section{REFERENCES}

1. Anderson, U. (2003), Chapter 4. Assurance and Consulting Services, pp. 98-129, in Bailey, A.D., Gramling, A.A., Ramamoorti, S. (Editors), Research Opportunities in Internal Auditing, Altamonte Springs: The Institute of Internal Auditors Research Foundation.

2. Bailey, J.A. (2010), The IIA's Global Internal Audit Survey: A Component of the CBOK Study- Core Competencies for Today's Internal Auditor-Inst of Internal Auditors, Report II, [pdf] Available at: https://na.theiia.org/iiarf/Public\%20Documents/201 0 -CBOK-Core-Competencies.pdf, [Accessed on August 2, 2016].

3. Barr-Pulliam, D. (2016), Engaging Third Parties for Internal Audit Activities. Strategies for Successful Relationships, [pdf] Available at: http://contentz.mkt5790.com//p/2842/199768/IIARF $\% 20$ CBOK\%20Engaging\%20Third\%20Parties $\% 20$ For\%20IA\%20Activities\%20Jan\%202016_0.pdf, [Accessed on August 2, 2016].

4. Boța-Avram, C. and Popa, I. (2011), Evolution of internal auditing in Romania: A critical analysis, International Journal of Disclosure and Governance, vol. 8, no. 4, pp.380-398.

5. Ernst \& Young (2013), Matching Internal Audit talent to business needs. Key findings from the Global Internal Audit Survey 2013, Available at: http://www.ey.com/GL/en/Services/Advisory/MIAtalent-to-business-needs---Key-findings-from-theGlobal-Internal-Audit-Survey-2013, [Accessed on August 2, 2016].

6. Flemming Ruud, T. (2003), Chapter 3. The Internal Audit Function: An Integral Part of Organizational Governance, pp. 74-96, in Bailey, A.D., Gramling, A.A., Ramamoorti, S. (Editors), Research Opportunities in Internal Auditing, Altamonte Springs: The Institute of Internal Auditors Research Foundation.

7. Harrington, L. and Piper, A. (2015), Driving Success in a Changing World. 10 Imperatives for Internal Audit, [pdf] Available at: http://contentz.mkt5790.com/lp/2842/188608/PIPE R_Ten_Imperatives.pdf, [Accessed on August 2, 2016].
8. IIA (2010), CBOK. Global Internal Audit Common Body of Knowledge. Resources Exchange, [online] Disponibil la:

https://na.theiia.org/iiarf/Pages/Common-Body-ofKnowledge-CBOK.aspx, [Accesat pe 09 august 2016].

9. IIA (2013), The IIA's Global Internal Audit Competency Framework, 2013, [pdf] Available at: https://na.theiia.org/about-us/aboutia/Pages/Competency-Framework.aspx, [Accessed on August 2, 2016].

10. IIA (2015), Core Principles for the Professional Practice of Internal Auditing, [pdf] Available at: https://na.theiia.org/standardsguidance/mandatory-guidance/Pages/CorePrinciples-for-the-Professional-Practice-of-InternalAuditing.aspx, [Accessed on August 2, 2016].

11. IOSCO (2005), Survey Report on Regulation and Oversight of Auditors, [pdf] Available at: http://www.iosco.org/library/pubdocs/pdf/ioscopd19 9.pdf, [Accessed on August 2, 2016].

12. Iyer, V. (2016), CAE Career Paths. Characteristics and Competencies of Today's Internal Audit Leaders, Available at: http://contentz.mkt5790.com/lp/2842/203310/IIARF $\% 20$ CBOK\%20CAE\%20Career\%20Path\%20Marc h\%202016.pdf, [Accessed on August 2, 2016].

13. Moeller, R.R. (2005), Brink's Modern Internal Auditing, 6th Edition, New York:John Wiley \& Sons, Inc.

14. Moeller, R.R. and Witt, H.N.(1999), Brink's Modern Internal Auditing, 5th Edition, New York: John Wiley \& Sons, Inc.

15. Precob, C.I. and Rusu-Buruiană, A. (2015), The Features of Internal Audit in Romania. Study on the Perception of Internal Auditors, Audit financiar, vol. 13, no. 9(129)/2015, pp. 77-90.

16. Ramamoorti, S. (2003), Chapter 1.Internal Auditing: History, Evolution, and Prospects, pp. 223, in Bailey, A.D., Gramling, A.A., Ramamoorti, S. (Editors), Research Opportunities in Internal Auditing, Altamonte Springs: The Institute of Internal Auditors Research Foundation. 
17. Ratliff, R.L. and Reading, O.F. (2002), Introduction to Auditing: Logic, Principles, and Techniques, Altamonte Springs: The Institute of Internal Auditors Research Foundation.

18. Rittenberg, L.E. (2016), Interacting with Audit Committees. The Way Forward for Internal Audit, [pdf] Available at:

http://contentz.mkt5790.com/lp/2842/201068/IIARF $\% 20$ CBOK\%20Interacting\%20with\%20Audit\%20C ommittees\%20FEB\%202016.pdf, [Accessed on August 2, 2016].

19. Rose, J. (2015), Mapping Your Career. Competencies Necessary for Internal Audit Excellence, [pdf] Available at: http://contentz.mkt5790.com/lp/2842/197389/IIARF \%20CBOK\%20Mapping\%20Your\%20Career\%20D ec\%202015_1.pdf, [Accessed on August 2, 2016].

20. Rose, J. (2016), The Top 7 Skills CAEs Want. Building the Right Mix of Talent for Your
Organization, [pdf] Available at: http://contentz.mkt5790.com/lp/2842/205617/IIARF $\% 20$ CBOK $\% 20$ TOP $\% 207 \% 20$ Skills $\% 20$ CAEs $\% 20$ Want\%20April\%202016.pdf, [Accessed on August 2, 2016].

21. Seago, J. (2015), Delivering on the Promise. Measuring Internal Audit Value and Performance, [pdf] Available at:

http://contentz.mkt5790.com/lp/2842/196909/IIARF $\% 20$ CBOK\%20Delivering\%20on\%20the\%20Promi se\%20Nov\%202015.pdf, [Accessed on August 2, 2016].

22. Tsintzas, E. (2016), Lifelong Learning for Internal Auditors. Certification and Training Levels Worldwide, [pdf] Available at: http://contentz.mkt5790.com/lp/2842/205616/IIARF $\% 20$ CBOK $\% 20$ Lifelong $\% 20$ Learning $\% 20$ for $\% 20$ Int ernal\%20Auditors\%20April\%202016_0.pdf, [Accessed on August 2, 2016]. 